\title{
Affinity Chromatography of Pseudomonas Isoamylase on Cross-linked Amylose Gel
}

\author{
Kanji Kato, Yoshio Konishi, Akinori Amemura and Tokuya Harada* \\ The Institute of Scientific and Industrial Research, Osaka University, \\ Yamada-kami, Suita-shi, Osaka 565, Japan
}

Received June 8, 1977

\begin{abstract}
The use of amylose gel cross-linked by epichlorohydrin for affinity chromatography of extracellular isoamylase of Pseudomonas amyloderamosa was studied. The isoamylase was adsorbed well on the amylose gel and was eluted specifically with maltodextrin. The eluted enzyme was precipitated with ammonium sulfate to remove maltodextrin, and then the solution of the precipitate was dialyzed and concentrated by vacuum filtration. By this procedure $96 \mathrm{mg}$ of the enzyme were purified to homogeneity from 20 liters of culture broth in about $70 \%$ yield.
\end{abstract}

Pseudomonas isoamylase ${ }^{1)}$ (glycogen 6-glucanohydrolase, EC 3.2.1.68) splits the branching points of amylopectin and glycogen completely. The enzyme is useful for elucidating the structures of amylopectin and glycogen and for commercial production of amylose and maltose from starch, alone and in combination with $\beta$-amylase. In previous works in this laboratory, the isoamylase was purified about 720 -fold in $23 \%$ yield from the culture fluid of the organism ${ }^{2,3)}$ and was also obtained in a crystalline form. ${ }^{4}$ ' Recently, we found that this isoamylase was adsorbed to raw starch. a-Amylases from Pseudomonas saccharophila ${ }^{51}$ and from Bacillus licheniformis ${ }^{61}$ are known to be adsorbed to starch. Sandstedt and Ueda ${ }^{7}$ reported the adsorption of four different $\alpha$-amylases on raw starch and the relation of this to digestion of the starch. The affinity of $\alpha$-amylase from Streptomyces aureofaciens for cross-linked starch was shown to be influenced by the presence of soluble substrates and proteins and the $\mathrm{pH}^{8)} \mathrm{Be}-$ cause of increasing interest in the structure, function and practical uses of Pseudomonas isoamylase, we developed a simple new procedure using amylose gel for its isolation.

* To whom reprint requests should be sent.

\section{MATERIALS AND METHODS}

Preparation of cross-linked amylose gel adsorbent. Amylose gel was prepared by a modification of the method of Matsumoto and Osawa ${ }^{9)}$ as follows. Amylose HyF-P was used as starting material, because branching points of amylopectin are split by the isoamylase but amylose is inert to it, although it is uncertain whether the branching points of cross-linked amylopectin gel are attacked by the isoamylase. A mixture of $30 \mathrm{ml}$ of $5 \mathrm{~N} \mathrm{NaOH}, 20 \mathrm{ml}$ of epichlorohydrin and $20 \mathrm{ml}$ of an aqueous suspension of $10 \mathrm{~g}$ potato amylose were stirred vigorously at $40^{\circ} \mathrm{C}$. The suspension solidified in $10 \mathrm{~min}$ as a gel cake. This was stood for $30 \mathrm{~min}$ at $40^{\circ} \mathrm{C}$, and then homogenized with a Universal Homogenizer from Nihon Seiki Co. The gel obtained was suspended in water and washed by decantation and the floating particles were discarded.

Preparation of crude isoamylase. Pseudomonas amyloderamosa $\mathrm{KiC}$ was used. It is a revertant strain of $\mathrm{Kl}$, which is deficient in isoamylase and is derived from an isoamylase constitutive mutant strain MSl. ${ }^{10)}$ Strain KlC produces isoamylase constitutively as well as intracellular $\alpha$-amylase and $\alpha$-glucosidase. It was cultured aerobically at $30^{\circ} \mathrm{C}$ for $96 \mathrm{hr}$ in the medium described by Harada et al. ${ }^{11}: 2 \%$ maltose, $0.4 \%$ sodium glutamate, $0.15 \%\left(\mathrm{NH}_{4}\right)_{2} \mathrm{HPO}_{4}, 0.1 \% \mathrm{KH}_{2} \mathrm{PO}_{4}, 0.05 \%$ $\mathrm{MgSO}_{4} \cdot 7 \mathrm{H}_{2} \mathrm{O}$, and $0.01 \%$ each of $\mathrm{FeCl}_{3} \cdot 6 \mathrm{H}_{2} \mathrm{O}, \mathrm{MnCl}_{2}$. $4 \mathrm{H}_{2} \mathrm{O}$ and $0.01 \% \mathrm{NaCl}$, at $\mathrm{pH} 5.5$. After culture, cells were removed by centrifugation and the supernatant was used for purification of the extracellular isoamylase.

Assay of isoamylase activity. The reaction mixture contained $0.5 \mathrm{ml}$ of $1 \%$ maize amylopectin and $0.4 \mathrm{ml}$ of $0.1 \mathrm{~m}$ acetate buffer, $\mathrm{pH} 3.5$. The mixture was incubated with $0.1 \mathrm{ml}$ of the enzyme solution at $40^{\circ} \mathrm{C}$ for 
$1 \mathrm{hr}$ and then the reducing power of the digest was measured by the method of Somogyi and Nelson. ${ }^{12)}$ One unit of enzyme activity is expressed as the amount liberating $1 \mu$ mole of aldehyde group as glucose per min.

Determination of protein concentration. Protein concentration was estimated by the method of Lowry et $a{ }^{13)}$ using bovine serum albumin as a standard. The amount of protein in effluents from columns was determined from the absorbance at $280 \mathrm{~nm}$, using a Hitachi 124 UV-VIS spectrophotometer.

Gel electrophoresis. Polyacrylamide gel electrophoresis was carried out at pH 8.3 by the method of Davis $^{14)}$ with a current of $3 \mathrm{~mA}$ for $1.5 \mathrm{hr}$, and then the gel was stained with Amido Black 10B.

Reagents. Amylose HyF-P (Hayashibara Biochemical Laboratory), prepared from potato starch by treatment with Pseudomonas isoamylase, ${ }^{15)}$ was used to make cross-linked amylose gel. Maltose and maltotriose were the products of Hayashibara Biochemical Laboratory.

Maltodextrin (Ran) was also supplied from Hayashibara Biochemical Laboratory. This preparation was obtained by hydrolysis of corn starch with Bacillus $\alpha$-amylase and about $60 \%$ of it was saccharides with a higher degree of polymerization than maltotetraose. It contained about $2.5 \%$ of saccharides that could not be removed by dialysis; these were removed by precipitation with two volumes of ethanol to prevent the purified enzyme from being contaminated. Maize amylopectin was purchased from Sigma Chemical Co. Isoamylase was purified in our laboratory as reported previously.1) Other chemicals were commercial products of the highest purity available.

\section{RESULTS AND DISCUSSION}

\section{Adsorption of enzymes on amylose gel}

We prepared cross-linked amylose gel and tested suitable conditions for its adsorption of Pseudomonas isoamylase. Results showed that isoamylase was adsorbed to the gel under acidic conditions ( $\mathrm{pH} 3.5 \sim 5.5$ ) where the enzyme is stable. To determine the optimal amount of amylose gel required for adsorption of the enzyme, we mixed various amounts of the gel in $2 \mathrm{ml}$ of $0.01 \mathrm{M}$ acetate buffer, $\mathrm{pH}$ 3.5 , with $2 \mathrm{ml}$ of buffer containing $170 \mu \mathrm{g}$ of isoamylase in a Micro Thermo-mixer (Thermonics Co.) for $1 \mathrm{~min}$ and then incubated the mixtures for $10 \mathrm{~min}$ at $4^{\circ} \mathrm{C}$, centrifuged them at $3000 \mathrm{rpm}$ for $10 \mathrm{~min}$ and measured the

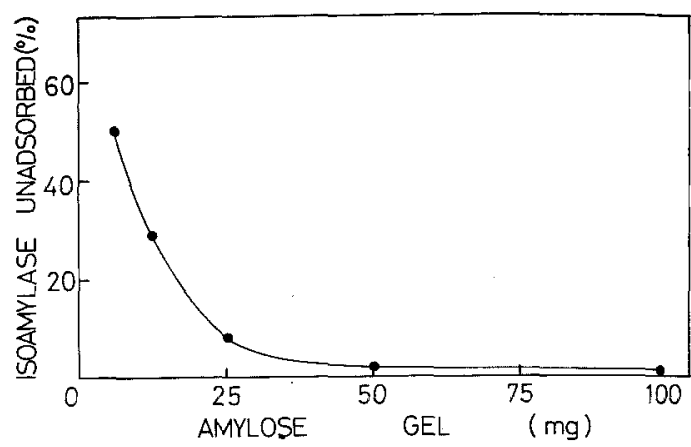

FIG. 1. Influence of the Amount of Amylose Gel on Adsorption of Isoamylase Activity.

The amount of gel is shown as dry weight.

enzyme activity of the supernatant. As shown in Fig. 1, $50 \mathrm{mg}$ of the gel adsorbed most of the enzyme, and one mg dry weight of the gel adsorbed about $3 \mu \mathrm{g}$ of isoamylase.

\section{Elution of isoamylase from an amylose gel column}

The abilities of various compounds to elute isoamylase from amylose gel were examined. For the tests isoamylase $(50 \mu \mathrm{g} / 10 \mathrm{ml})$ was applied to columns $(7 \times 50 \mathrm{~mm})$ of amylose gel at $4^{\circ} \mathrm{C}$. No activity could be eluted with $0.1 \mathrm{M}$ acetate buffer $(\mathrm{pH} \quad 3.0 \sim 5.5), 0.1 \mathrm{M}$ phosphate buffer ( $\mathrm{pH} 5.5 \sim 7.5)$ or $0.1 \mathrm{M}$ ammonium buffer ( $\mathrm{pH} 8.0 \sim 9.0$ ). Elutions with solutions of 1 to $20 \%$ sodium chloride were

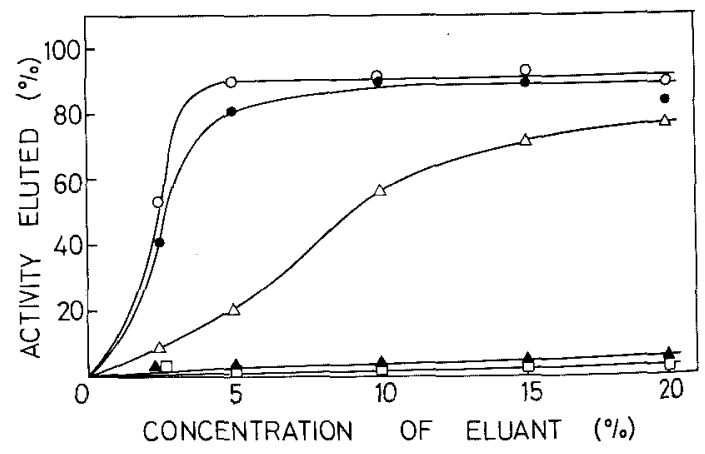

FIG. 2. Elution of Isoamylase from Amylose Gel. Isoamylase $(50 \mu \mathrm{g})$ adsorbed to amylose gel was eluted with $20 \mathrm{ml}$ of solutions of maltodextrin $(0)$, maltotriose $(\boldsymbol{O})$, maltose $(\Delta)$, glucose $(\boldsymbol{\Lambda})$ and sodium chloride ( $\square$ ). Recovery of the enzyme in the eluate is shown. 
also tested under the same conditions, dialyzing the eluate against $0.01 \mathrm{M}$ acetate buffer, $\mathrm{pH} 3.5$, before measuring activity to avoid the effect of salt on the assay. However, less than $5 \%$ of the isoamylase was eluted from the column with any of the concentrations of sodium chloride tested (Fig. 2). Solutions of maltodextrin, prepared from corn starch by treatment with Bacillus $\alpha$-amylase, maltotriose, a competitive inhibitor of isoamylase ${ }^{16)}$ and maltose were also examined (Fig. 2). Most of the adsorbed enzyme could be eluted with these compounds, but higher concentrations of maltose than of maltotriose and maltodextrin were required: 5 percent aqueous solutions of maltodextrin and maltotriose eluted almost all the isoamylase from the gel.

\section{Purification of isoamylase using amylose gel}

The isoamylase from Pseudomonas amyloderamosa $\mathrm{KIC}$ was purified as follows. All operations were carried out at $4{ }^{\circ} \mathrm{C}$. Twenty liters of culture supernatant were divided into two portions. Each portion (10 liters) was directly applied to a column $(65 \times 210 \mathrm{~mm})$ of the amylose gel equilibrated with $0.01 \mathrm{M}$ acetate buffer, $\mathrm{pH}$ 3.5. The column was washed with 7 liters of the same buffer containing $0.5 \mathrm{M} \mathrm{NaCl}$ and then isoamylase was eluted with $1500 \mathrm{ml}$ of $5 \%$ maltodextrin in the same buffer. The flow rate was $330 \mathrm{ml}$ per $\mathrm{hr}$ and $100 \mathrm{ml}$ fractions were collected. The elution pattern is shown in Fig. 3. The fractions of effluent containing the enzyme were pooled and treated with $60 \%$ saturation of ammonium sulfate. The resulting precipitate was collected by centrifugation, dissolved in $20 \mathrm{ml}$ of $0.01 \mathrm{M}$ acetate buffer, $\mathrm{pH} 3.5$ and dialyzed and concentrated against $0.01 \mathrm{M}$

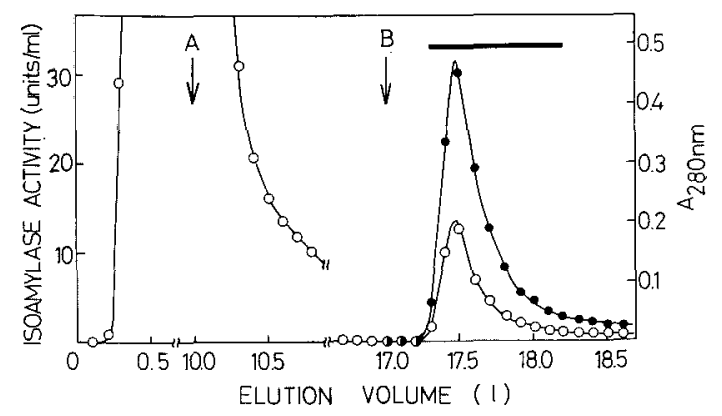

FIG. 3. Column Chromatogram of Isoamylase on Amylose Gel.

Arrows A and B indicate the points at which elution with $0.01 \mathrm{M}$ acetate buffer (pH 3.5) containing $0.5 \mathrm{M}$ sodium chloride and the same buffer containing $5 \%$ maltodextrin respectively were started. The solid bar indicates the fractions pooled for further purification. $O$, absorbance at $280 \mathrm{~nm}$; $\bullet$, isoamylase activity.

acetate buffer, $\mathrm{pH} 3.5$, by vacuum filtration through a collodion membrane. In this way the isoamylase was purified 93-fold from the culture supernatant in a yield of $70 \%$, as summarized in Table I. About $96 \mathrm{mg}$ of the enzyme were obtained from 20 liters of culture supernatant. Electrophoresis on polyacrylamide gel gave a single protein band (Fig. 4). This affinity chromatography is much simpler and gives a better yield than the previous method involving 5 steps of purification. ${ }^{2}$ The column of amylose gel could be used repeatedly: little or no loss of binding capacity of the column was detected in one month during repeated use.

Fortunately, the culture supernatant of Pseudomonas amyloderamosa does not contain other amylases, such as $\alpha$-amylase, glucoamylase and $\alpha$-glucosidase. If they were present they would also be adsorbed to the amylose

Table I. Enzyme Purification

\begin{tabular}{|c|c|c|c|c|c|}
\hline \multirow{2}{*}{ Step of purification } & \multirow{2}{*}{$\begin{array}{l}\text { Vol. } \\
\text { (ml) }\end{array}$} & \multirow{2}{*}{$\begin{array}{l}\text { Protein } \\
\text { (mg) }\end{array}$} & \multicolumn{3}{|c|}{ Activity } \\
\hline & & & Units & $\begin{array}{l}\text { Yicld } \\
(\%)\end{array}$ & $\begin{array}{c}\text { Specific } \\
\text { activity } \\
\text { (units/mg) }\end{array}$ \\
\hline Crude filtrate & 20000 & 12800 & 26100 & $(100)$ & 2.04 \\
\hline Amylose gel & 1800 & 111 & 21100 & 81 & 190 \\
\hline$\left(\mathrm{NH}_{4}\right)_{2} \mathrm{SO}_{4} 0 \sim 60 \%$ & 20 & 96.2 & 18300 & 70 & 190 \\
\hline
\end{tabular}




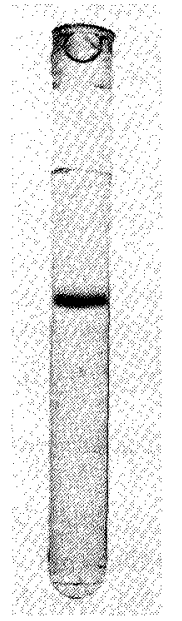

FIG. 4. Polyacrylamide Disc Electrophoresis of Isoamylase at pH 8.3.

Approximately $0.1 \mathrm{mg}$ of protein was applied to the gel. Electrophoresis was carried out for $2.5 \mathrm{hr}$ at $2.0 \mathrm{~mA}$ at $4^{\circ} \mathrm{C}$. The gel was stained with Amido Black dye.

gel and more strict conditions would be necessary for preparing the gel or adsorbing the isoamylase on it.

Acknowledgements. The authors would like to express their thanks to Hayashibara Biochemical Laboratory for valuable gifts of materials used in this work. This work was supported by a grant from the Japanese Ministry of Education, Science and Culture.

\section{REFERENCES}

1) T. Harada, Memo. Inst. Sci. Ind. Res., Osaka Univ., 34, 49 (1977).

2) K. Yokobayashi, A. Misaki and T. Harada, Biochim. Biophys. Acta, 212, 458 (1970).

3) K. Yokobayashi, A. Misaki and T. Harada, Agric. Biol. Chem., 33, 625 (1969).

4) T. Harada, A. Misaki, H. Akai, K. Yokobayashi and K. Sugimoto, Biochim. Biophys. Acta, 268, 497 (1972).

5) A. Markowitz, H. P. Klein and E. H. Fisher, ibid,, 19, 267 (1956).

6) N. Saito, Arch. Biochem. Biophys., 155, 290 (1973).

7) R. M. Sandstedt and S. Ueda, J. Jap. Soc. Starch Science, 17, 215 (1969).

8) E. Hostinova and J. Z. Bratislava, Die Stärke, 27, 343 (1975).

9) I. Matsumoto and T. Osawa, Biochem. Biophys. Res. Commun., 46, 1810 (1972).

10) Kapti R. Kuswanto, K. Kato, A. Amemura and T. Harada, J. Ferment. Technol., 54, 192 (1976).

11) T. Harada, K. Yokobayashi and A. Misaki, Appl. Microbiol., 16, 1439 (1968).

12) J. Nelson, J. Biol. Chem., 153, 375 (1944).

13) O. H. Lowry, N. J. Rosebrough, A. L. Farr and R. J. Randall, ibid., 193, 265 (1951).

14) B. J. Davis, Ann. N. Y. Acad. Sci., 121, 404 (1964).

15) H. Akai, K. Yokobayashi, A. Misaki and T. Harada, Biochim. Biophys. Acta, 252, 427 (1971).

16) H, Kitagawa, A. Amemura and T. Harada, Agric. Biol. Chem., 39, 989 (1975). 